\title{
The effects of Ponzi schemes and revocation of licences of some financial institutions on financial threat in Ghana
}

\author{
Edmond Ofori
}

Department of Accounting, West End University College, Accra, Ghana

\begin{abstract}
Purpose - The purpose of this study was to assess the effects of the Ponzi schemes and revocation of licences of some financial institutions in Ghana on financial threat.

Design/methodology/approach - The study adopted a quantitative research approach. Convenient sampling method was used to select 435 individuals from three regions in Ghana. Standardize questionnaire developed by the researcher was used as the main data collection instrument. The binary logistic regression was used to test the relationship between the dependent variable and the independent variables.

Findings - The results of the study showed a positive relationship between financial threat and job loss, general health, information search and loss of investment. However, negative relationship was identified between financial threat and total debt, stress, economic hardship and anxiety. Findings from this study imply that job loss, general health, information search and loss of investment are major factors that determined financial threat in Ghana.

Practical implications - This indicates that individuals in Ghana have become uncertain regarding the use of current and future financial services in Ghana because most individuals have lost their jobs in the financial institutions, cannot get access to safe drinking water and education, need to gather more information before investing in financial institutions in Ghana and losing of funds invested.

Originality/value - This study is the first to test the effects of the Ponzi schemes and the revocation of licences of some financial institutions in Ghana on financial threat using binary logistic regression.
\end{abstract}

Keywords Binary logistic regression, Financial institutions, Financial threat, Ponzi schemes, Ghana

Paper type Research paper

\section{Introduction}

Ghana's financial sector has experienced a lot of Ponzi schemes and revocation of licences of insolvent savings and loans companies, finance house companies, microfinance and banking institutions between 2015 and 2019 (Bank of Ghana, 2019b). In 2015, DKM Diamond Microfinance Company Limited, Little Drops Financial Services, God is Love Fun Club, Jaster Motors and Investment Limited and Care for Humanity Fun Club, which were located in most parts of Bono Region, Bono East Region, Upper West Region and Upper East Region of Ghana were involved in Ponzi schemes (GBN, 2016). Ponzi schemes are

(C) Edmond Ofori. Published by Emerald Publishing Limited. This article is published under the Creative Commons Attribution (CC BY 4.0) licence. Anyone may reproduce, distribute, translate and create derivative works of this article (for both commercial and non-commercial purposes), subject to full attribution to the original publication and authors. The full terms of this licence may be seen at http://creativecommons.org/licences/by/4.0/legalcode 
JFC

30,2

584

fraudulent investments opportunities that promise high rates of return with low risk to investors but fail in the long run (Chen, 2019). These institutions created investment instruments with high interest return of over 40 per cent for two or three month's period. These institutions offered interest rates higher than the base rate of 24 or 25 per cent per annum offered by government securities, which were risk free (Larbi, 2016). These unsustainable investment instruments attracted some users of financial services in Ghana to invest in them. These financial service users were interested in allowing their assets to work for them rather than working with their assets. Bank of Ghana shut down these institutions in 2015, as, their activities contravene the rules of Bank of Ghana and some were unlicenced (Owusu, 2018). Affected victims of DKM Diamond Microfinance Company Limited that officially applied to the official liquidator for their invested funds were 99,858 and Little Drops Financial Services, God is Love Fun Club, Jaster Motors and Investment Limited and Care for Humanity Fun Club were also more than 21,000 (Ofori-Atta, 2018).

In the year 2016, Bank of Ghana again revoked the licences of 70 microfinance and money lending companies in Ghana after the companies failed to complete the necessary documentations for the final approval of their licences after the expiration of their provisional licences (The Financial Intelligence Centre, 2016). GCB bank limited took over UT Bank Limited and capital bank limited in 2017 after GCB bank purchased these two banks due to the severe impairment of the banks' capital. The takeover resulted in the revocation of the banking licences of UT Bank Limited and capital bank limited in 2017 (Joy Business, 2017). Menzgold Ghana limited was a gold dealership and investment firm in Ghana. Menzgold Ghana limited ceased operations in 2018 after its licence was revoked by the Minerals Commission of Ghana. This company was involved in gold trading and export (Securities and Exchange Commission Ghana, 2018). Bank of Ghana created Consolidated Bank Ghana in 2018 to takeover Sovereign bank, Royal Bank, The Beige Bank, Construction Bank and Unibank, as these banks were facing liquidity challenges (Frimpong, 2018). In 2019, Bank of Ghana again revoked the licences of 23 insolvent savings and loans companies and finance house companies (Bank of Ghana, 2019b). Again in 2019, Ghana's Securities and Exchange Commission revoked the licences of 53 securities, fund management companies in Ghana (Securities and Exchange Commission Ghana, 2019). These 53 fund management companies served as an indirect channel for Ghanaian investors to invest their funds. These Ponzi schemes and revocation of licences of some financial institutions in Ghana have affected the emotions of Ghanaians. Ghanaians are emotionally affected because of the creation of unemployment, loss of invested funds, collapse of businesses and other economic hardship created by the scandals and revocation of licences of some financial institutions in Ghana. Research works in other countries have shown that these emotional effects have caused some users of financial services to lose their lives, abusing alcohol and psychological distress (Kaplan et al., 2015). These emotional effects can be described as financial threat, which deals with the uncertainty regarding the use of current and future financial services by financial services users (Lisa et al., 2017). This financial threat can affect individuals to change their financial behaviour. Available data indicate that over 101,958 Ghanaians have been affected by the scandals and revocation of licences of some financial institutions in Ghana (Ofori-Atta, 2018).

Currently, there are no empirical studies in Ghana, which have examined the effects of the Ponzi schemes and revocation of licences of some financial institutions on individuals in Ghana, which may be associated with financial threat. The main purpose of these empirical studies is to assess the effects of the Ponzi schemes and revocation of licences of some financial institutions in Ghana on financial threat. The paper proceeds with the following 
sections: Sections 2 and 3 describes literature review and research methodology. Section 4 presents empirical results and discussion. Section 5 derives conclusions.

\section{Literature review}

Causes of the Ponzi schemes and revocation of licences of insolvent financial institutions in Ghana

DKM Diamond Microfinance Company Limited in 2015 was suspended by Bank of Ghana for failing to comply with terms and conditions stipulated in its licence, not having adequate assets to cover its liabilities to depositors, offering high interest to investors, which was detrimental to the interest of the depositors of company, violating statutory restrictions on exposures and setting up of subsidiary companies, which was against the restrictions of establishing subsidiary companies (GBN, 2016). Audit conducted by Bank of Ghana showed that DKM Diamond Microfinance Company Limited had a total deposit liability of GHC $115.24 \mathrm{~m}$ against a total of cash of GHC 10.8m (Larbi, 2016). An amount of GHC 77.26m was also diverted to DKM Diamond Microfinance Company Limited subsidiaries (Eben, 2016).

Collapsing of some of the financial institutions resulted in the withdrawals of their operating licences. Some of the financial institutions collapsed as a result of poor corporate governance. The board and senior management of these institutions fail to perform their functions well (Owusu, 2018). This paved the way for some management members to engage in activities that promoted their personal interest than promoting the growth of these financial institutions. Some senior management members of the financial institutions such as the banks obtained loans from their banks, which they failed to pay increasing the non-performing loans of the banks (Larbi, 2016). Board members of the collapse banks failed to ensure that their banks followed the corporate reporting systems and external audit system. Board of directors of these banks did not ensure proper functioning of the risk management framework of the banks. Chief internal auditors of the collapse banks contributed to the collapsing of their banks. These Auditors failed to report the wrong doings of the executive directors of the banks to the board of directors of the bank (Owusu, 2018).

Non-performing loans also contributed to the collapse of some of the financial institutions. Non-performing loans were identified by Bank of Ghana to be high on the balance sheet of the collapse banks. The high non-performing loans increased the operating costs of the banks reducing the profitability of the banks and tied up capital of the banks. These non-performing loans increased because of the increase in loans default by borrowers. Loans were approved without due diligence and proper credit risk assessment (Afolabi, 2018).

Bank of Ghana lapses in regulating and supervising the banking system in Ghana also contributed to the collapse of the savings and loans companies, finance house companies, microfinance and banking institutions between 2015 and 2019. These lapses allowed the banks not to comply with the rules and regulations established by Bank of Ghana. This resulted in the vulnerabilities in the banking sector (Sarfo, 2018).

Some of the banks' licences were withdrawn because those licences were obtained under false pretense. Construction bank was identified by Bank of Ghana to have obtain its licence by false pretense by using suspicious and non-existent of capital. Capital bank was also reported by Bank of Ghana to have obtained their licence through false pretense (Myjoyonline.com, 2018).

Menzgold licence was withdrawn by securities and exchange commission in 2018 and prevented the company from trading in gold (Securities and Exchange Commission Ghana, 2018). The securities and exchange commission found Menzgold in dealing in buying and 
deposit of gold collectibles from the public and entering into contract with them. These contracts guaranteed customers with high interest returns. Menzgold offered these investment instruments without a valid licence from the securities and exchange commission. The activities of Menzgold were in contravention of Section 109 of Act 929 of the securities and exchange commission, which accounted for the withdrawal of their operating licence (Oka, 2018).

The reasons raised by Bank of Ghana as the causes of the collapse of some of the banks in Ghana show that the banks failed not because of bank run whereby large number of customers decide to withdraw their deposits due to the loss of the public confidence in the banking sector in Ghana and stock market failure but because of the banks own mismanagement of their activities and regulatory failure (Owusu, 2018).

\section{Effects of the Ponzi schemes and revocation of licences of insolvent financial institutions in Ghana}

These Ponzi schemes and revocation of licences of insolvent financial institutions in Ghana may affect Ghana's financial market in the following ways. The identification of high nonperforming loans as a contributing factor to the collapsing of some of the banks may influence banks currently operating in Ghana to reducing the amount of money they lend to their consumers. Businesses with high risks will be affected heavily in securing loans. This may reduce the ability of these businesses to invest more and employ more employees (Anokye, 2019). This may affect the growth of the economy and increase unemployment in Ghana as some employees may lose their jobs and others may not be able to seek jobs (Vaultz, 2019).

The employees of the collapse financial institutions have now become unemployed, which may have affected their income level. Individuals have also lost their invested funds. This may force affected people to borrow money from their family and friends to survive and some may have physical, mental and emotional disorder. It may also have affected individuals' access to safe drinking water, nutritious foods, education and adequate housing (Anokye, 2019).

It has also increased government debt as Government of Ghana has to look for funds to assist the official receiver to pay depositors of affected institutions (Bank of Ghana, 2019a). The confidence level of Ghanaians and other people outside Ghana in the financial sector will reduce as the risks level in the financial market have increased. It has also undermined the reputation of political authorizes, regulators and law enforcers in Ghana. Financial service users may prefer to keep their money in their houses than saving or investing them in the financial institutions, which will affect the financial institutions ability to support economic activities to grow in Ghana (Vaultz, 2019).

\section{Research methodology}

The study adopted a quantitative research approach. This research approach was used to assess the effects of the Ponzi schemes and revocation of licences of some financial institutions in Ghana on financial threat. For the purpose of this study, the researcher targeted Ghanaians of 18 years and above who have the legal right to use financial services in Ghana. The participants for the study were selected from the Bono Region, Bono East Region and the Greater Accra Region. These regions were used by the researcher because these regions were heavily affected by the scandals and revocation of licences of some financial institutions in Ghana (Larbi, 2016). Convenient sampling method was used to select 435 individuals from the three regions. Convenient sampling method provided the 
researcher the chance to select respondents that were accessible and willing to participate in the study. The researcher selected 145 individuals from each region randomly.

Based on review of existing literature standardize questionnaire developed by the researcher was used as the main data collection instrument. The consent of the respondents was also sought through a brief introduction on the researcher's objectives and relevance of the study before the questionnaires were distributed to the respondents for them to answer. The questionnaires were distributed to the respondents personally by researcher. The respondents were brief on how they should provide their responses. They were given enough time to answer the questions pose to them. The questionnaires were collected immediately from the respondent after they have finished answering the questions on the questionnaire for data editing and entering. The data for the study was collected over two months (September to October, 2019) period. Financial threat (FT) was used as the dependent variable. Independent variables used for the study included total debt $(T D)$, loss jobs $(L J)$, stress $(S)$, general health $(G H)$, economic hardship $(E H)$, anxiety $(A)$, information search $(I S)$ and loss of investment ( $L I)$. Data collected for the study was analyzed using the IBM statistical package for social sciences. The general binary logistic regression model was adopted by the researcher to test the effects of the Ponzi schemes and revocation of licences of some financial institutions on the financial threat of financial users in Ghana. Binary logistic regression was used, as the dependent variable financial threat has two outcomes (whether the financial users have been threatened to stop using financial services in Ghana or otherwise). The model takes the general form (Kabiru and Abdullahi, 2016):

$$
\mathrm{Z}=\ln [\mathrm{p} /(1-\mathrm{p})]=\beta_{0}+\mathrm{B}_{1} \mathrm{X}_{1}+\mathrm{e}
$$

From Model 1 " $1 \mathrm{n}$ " represented the natural logarithm, " $p$ " represented the probability that the dependent variable $(Z)$ equals $1, p(Z=1)$, "1- $p$ " represented the probability that dependent variable $(Z)$ equals $0, p(Z=0), \beta_{0}$ represented the constant, $\mathrm{B}_{1}, \mathrm{~B}_{2}$ and $\mathrm{B}_{3}$ indicated the regression coefficients of the independent variables, $X_{1}, X_{2}$ and $X_{3}$ indicated the independent variables and e represented the stochastic disturbance (error term). Based on the general form of the model the researcher used the following model for the study:

$$
\begin{aligned}
\mathrm{FT} & =\ln [\mathrm{p} /(1-\mathrm{p})] \\
& =\beta_{0}+\mathrm{B}_{1} \mathrm{TD}+\mathrm{B}_{2} \mathrm{LJ}+\mathrm{B}_{3} \mathrm{~S}+\mathrm{B}_{4} \mathrm{GH}+\mathrm{B}_{5} \mathrm{EH}+\mathrm{B}_{6} \mathrm{~A}+\mathrm{B}_{7} \mathrm{JS}+\mathrm{B}_{8} \mathrm{LI}+\mathrm{e}
\end{aligned}
$$

Where:

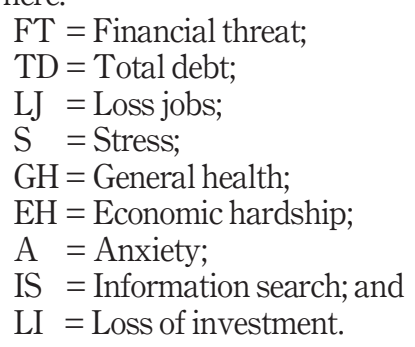

From the reviewed of theoretical and empirical studies related to this study the researcher hypothesized the following relationships between the dependent variable and independent variables used for this study: 
JFC

30,2

\section{8}

\section{Measurement of variables}

Table 1 provides information concerning how the research measured the variables used for this study.

\section{Empirical results and discussion}

Summary statistics of socio demographic characteristics of the respondents

Table 2 presents the descriptive statistics of the 435 respondents who responded to the questionnaires administered by the researcher. The results reviewed that out of the 435 respondents 229 were male representing 52.6 per cent and 206 were female representing 47.4 per cent. Majority (211) of the respondents indicating 48.5 per cent ages were from 25-34 while the minority (24) of the respondents indicating 5.5 per cent ages were 50 and above. Majority (254) of the respondents were having degree certificates whereas minority (4) of the

Variable Description

Financial threat $(F T)$

Financial threat was measured as the uncertainty regarding the use of current

Total debt $(T D)$ and future financial services by financial services users

Totaldebt (TD)

Total debt was measured as the amount borrowed by financial services users in Ghana as a result of losing their jobs and their investments in the collapsed financial institutions. This was to capture whether financial service users were

Loss jobs $(L J)$ forced to borrow money to survive or otherwise Loss jobs was captured a number of people who have lost their jobs. This was

Stress $(S)$ able to reveal the percentage of the respondents who have lost the jobs due to the collapsing of some financial institutions

Stress

Stress of the respondents was measured as the body reaction of the respondents with their physical, mental and emotions to the news concerning the collapsing of some of financial institutions. This assisted the researcher to find out how the respondents reacted when the news concerning the collapse financial institutions broke out

General health $(\mathrm{GH}) \quad$ General health was measured as the ability of the respondents to get access to safe drinking water, nutritious foods, education and adequate housing. This was to assess whether there has been a change in the respondents access to safe drinking water, nutritious foods, education and adequate housing because of the collapsing of some financial institutions

Economic hardship $(E H)$ This variable was measured as the difficulties of individuals of not having money for necessaries. This variable was used to assess the ability of the

Anxiety $(A)$ respondent to meet basic requirements of life such as food, clothing and warmth Anxiety was measured as the mental disorder of the respondents. This variable was used to find out if the respondents had any mental disorder when the news concerning the collapse financial institutions broke out

Table 1.

Measurement of variables
Information search (IS)

Loss of investment
This variable was adopted to measure the preparatory information gathered by individuals before they select and invest in financial institutions This variable was used to measure the amount of money individuals have lost as a results of the collapse of their financial institutions 


\begin{tabular}{|c|c|c|c|}
\hline Variable & Frequency & $(\%)$ & Financial \\
\hline $\begin{array}{l}\text { Sex } \\
\text { Male } \\
\text { Female } \\
\text { Total }\end{array}$ & $\begin{array}{l}229 \\
206 \\
435\end{array}$ & $\begin{array}{r}52.6 \\
47.4 \\
100.0\end{array}$ & Ghana \\
\hline $\begin{array}{l}\text { Age } \\
18-24 \\
25-34 \\
35-49 \\
50 \text { and above } \\
\text { Total }\end{array}$ & $\begin{array}{r}153 \\
211 \\
47 \\
24 \\
435\end{array}$ & $\begin{array}{r}35.2 \\
48.5 \\
10.8 \\
5.5 \\
100.0\end{array}$ & 589 \\
\hline $\begin{array}{l}\text { Education } \\
\text { SHS } \\
\text { Vocational } \\
\text { Diploma } \\
\text { Degree } \\
\text { Master } \\
\text { PhD } \\
\text { Total }\end{array}$ & $\begin{array}{r}50 \\
31 \\
82 \\
254 \\
14 \\
4 \\
435\end{array}$ & $\begin{array}{r}11.5 \\
7.1 \\
18.9 \\
58.4 \\
3.2 \\
0.9 \\
100.0\end{array}$ & \\
\hline $\begin{array}{l}\text { No. of years of } \\
1-5 \\
6-10 \\
11-15 \\
16 \text { and above } \\
\text { Total }\end{array}$ & $\begin{array}{r}202 \\
73 \\
82 \\
78 \\
435\end{array}$ & $\begin{array}{r}46.4 \\
16.8 \\
18.9 \\
17.9 \\
100.0\end{array}$ & \\
\hline $\begin{array}{l}\text { Having accoun } \\
\text { Yes } \\
\text { No } \\
\text { Total }\end{array}$ & $\begin{array}{l}217 \\
218 \\
435\end{array}$ & $\begin{array}{r}49.9 \\
50.1 \\
100.0\end{array}$ & $\begin{array}{r}\text { Table } 2 . \\
\text { Descriptive statistics } \\
\text { of the respondents }\end{array}$ \\
\hline
\end{tabular}

respondents were having a $\mathrm{PhD}$. The findings discovered that majority (202) representing 46.4 per cent of the respondents have used financial services from 1-5 years whilst minority (73) indicating 16.8 per cent of the respondents have used financial services from 6-10 years. Out of the 435 respondents 217 representing 49.9 per cent were having accounts with the affected financial institutions whereas 218 representing 50.1 per cent were not having account with the affected financial institutions.

\section{Binary logistic regression results}

Table 3 displays the results for the general evaluation of the fitness of the model adopted by the researcher for this study. The results were generated by running the Hosmer-Lemeshow test and the Cox and Snell $R^{2}$ and Nagelkerke $R^{2}$ tests. The rule of Hosmer-Lemeshow test

\begin{tabular}{lccrr}
\hline Step & Chi-square & Df & Sig. & $\begin{array}{r}\text { Table 3. } \\
\text { Overall model } \\
1\end{array}$ Cox and Snell $R$ square $=0.252^{\text {Nagelkerke } R \text { square }=0.323}$ \\
\hline
\end{tabular}


JFC

30,2

590

states that a model is fit for a study if the model obtains a significant level greater than 0.05 (5 per cent) whereas the model is not fit for a study if the model obtains a significant level less than 0.05 (5 per cent). The results indicated a Chi-square value of 4.420 , with 8 degrees of freedom and significant level of 0.817 ( 81.7 per cent). The results imply that the model is fit for the study, as the significant level is greater the 5 per cent. The results provide statistical support for the researcher to report the findings of this study. The $R^{2}$ quares developed by Cox and Snell and Nagelkerke were 0.252 (25.2 per cent) and 0.323 (32.3 per cent), respectively. Cox and Snell and Nagelkerke $R^{2}$ summarize the proportion of variance in the dependent variable (financial threat) associated with the independent variables: total debt $(T D)$, loss jobs $(L J)$, stress $(S)$, general health $(G H)$, economic hardship $(E H)$, anxiety $(A)$, information search (IS) and loss of investment $(L I)$.

Table 4 displays the results of the relationships between the dependent variable and the independent variables. The results indicated a negative relationship between financial threat and total debt. This means that as the total debt of individuals increases financial threat decreases. Individuals borrowing money to meet their basic needs to survive because of the collapsing of some financial institutions in Ghana cannot influence individuals not to use financial services. The odd ratio of total debt is less than one confirming the negative relationship between total debt and financial threat. The odd ratio implies that the negative relationship between total debt and financial threat is less likely to occur with 95 per cent confidence level of 0.459 to 1.341 . The results support the researcher's hypothesis of negative relationship between financial threat and total debt. However, this negative relationship is not significant in determining financial threat.

The study also found a positive relationship between financial threat and loss jobs. Individuals losing their jobs as a result of the collapsing of some financial institutions in Ghana was identified as significant factor in predicting financial threat. This implies that as financial institutions collapses and individuals loses their jobs the more individual do not want to use financial services. The odd ratio results indicate a positive relationship between loss jobs and financial threat. Positive relationship exhibited by the odd ratio of loss job shows that the probability of loss job influencing financial is likely to occur with 95 per cent confidence level of 1.703 to 5.258. The results affirms the researcher's hypothesis of positive relationship between financial threat and loss jobs.

The study results show that stress has a negative significant impact on financial threat. The results means that the higher the physically and emotionally stress faced by individuals the lesser the individuals are uncertain regarding the use of current and future financial services. The results of the odd ratio reveal a negative relationship between stress and

Table 4.

Predictors of financial threat

\begin{tabular}{|c|c|c|c|c|c|c|c|c|}
\hline \multirow[b]{2}{*}{ Variables } & \multirow[b]{2}{*}{ B } & \multirow[b]{2}{*}{ S.E. } & \multirow[b]{2}{*}{ Wald } & \multirow[b]{2}{*}{ Df } & \multirow[b]{2}{*}{ Sig. } & \multirow[b]{2}{*}{ Odd ratio $\left(e^{\mathrm{B}}\right)$} & \multicolumn{2}{|c|}{$\begin{array}{l}95 \% \text { C.I. for EXP } \\
\text { (B) }\end{array}$} \\
\hline & & & & & & & Lower & Upper \\
\hline Total debt & -0.243 & 0.274 & 0.788 & 1 & 0.375 & 0.784 & 0.459 & 1.341 \\
\hline Loss jobs & 1.096 & 0.288 & 14.513 & 1 & 0.000 & 2.992 & 1.703 & 5.258 \\
\hline Stress & -0.517 & 0.234 & 4.904 & 1 & 0.027 & 0.596 & 0.377 & 0.942 \\
\hline General health & 0.424 & 0.276 & 2.359 & 1 & 0.012 & 1.528 & 1.890 & 2.624 \\
\hline Economic hardship & -0.439 & 0.274 & 2.564 & 1 & 0.109 & 0.645 & 0.377 & 1.103 \\
\hline Anxiety & -0.432 & 0.252 & 2.947 & 1 & 0.086 & 0.649 & 0.396 & 1.063 \\
\hline Information search & 0.537 & 0.270 & 3.965 & 1 & 0.044 & 1.711 & 1.008 & 2.902 \\
\hline Loss of investment & 0.743 & 0.220 & 11.363 & 1 & 0.001 & 2.102 & 1.365 & 3.237 \\
\hline Constant & -2.084 & 0.816 & 6.529 & 1 & 0.011 & 0.124 & & \\
\hline
\end{tabular}


financial threat. This implies that the probability of stress not to influence financial threat is not likely to occur with 95 per cent confidence level of 0.377 to 0.942 . The results rejects the researcher's hypothesis of positive relationship between financial threat and stress.

General health was identified to have positive and significant with financial threat. This implies that as the general health of individuals increases financial threat increases. As the ability of the individuals to get access to safe drinking water, nutritious foods, education and adequate housing is negatively affected the higher the individuals are uncertain regarding the use of current and future financial services. The odd ratio displays a positive relationship between general and financial threat. The likelihood of general health impacting positively on financial threat is high with 95 per cent confidence level of 10,890 to 2.624. The results support the researcher's hypothesis of positive relationship between financial threat and general health.

Economic hardship and anxiety were found in this study to have negative insignificant relationship with financial. This results indicate that economic hardship and anxiety do not have any influence on financial threat. Economic hardship and anxiety odd ratios show a negative relationship between them and financial threat. The probability of occurrence of these relationships are low with 95 per cent confidence level of 0.377 to 1.103 and 0.396 to 1.063 , respectively. The researcher's hypotheses of negative relationship between financial threat and these two variables were not affirm by the results of the study.

Information search was found in the study to have positive relationship with financial threat. The results imply a significant relationship between information search and financial threat. As individuals need to search for more information regarding financial institutions before investing their funds the greater individuals are uncertain regarding the use of current and future financial services. The odd ratio of information search reveals a positive relationship and likelihood events occurring with 95 per cent confidence level of 1.008 to 2.902 between information search and financial threat. The results support the researcher's hypothesis of positive relationship between financial threat and information search. Hence, information search has great impact on financial threat.

The study revealed that loss of investment is positively related to financial threat. Loss of investment is statistically significant in explaining financial threat. The greater individuals loss their investment in financial institutions the greater they become uncertain regarding the use of current and future financial services. The odd ratio suggests a positive relationship between loss of investment and financial threat. The probability of loss of investment causing financial threat is high with 95 per cent confidence level of 1.365 to 3.237 according to the results of the odd ratio. The results affirms the researcher's hypothesis of positive relationship between financial threat and loss of investment.

\section{Conclusions}

The study adopted a quantitative research approach. This research approach was used to assess the effects of the scandals and revocation of licences of some financial institutions in Ghana on financial threat. Convenient sampling method was used to select 435 individuals from three regions in Ghana. Standardize questionnaire developed by the researcher was used as the main data collection instrument. Binary logistic regression was used to test the relationship between dependent variable and the independent variables. The results of the study showed a positive relationship between financial threat and job loss, general health, information search and loss of investment. However, negative relationship was identified between financial threat and total debt, stress, economic hardship and anxiety. Findings from this study imply that job loss, general health, information search and loss of investment are major factors that determined financial threat in Ghana. This indicate that 
individuals in Ghana have become uncertain regarding the use of current and future financial services in Ghana because most individuals have lost their jobs in the financial institutions, cannot get access to safe drinking water, nutritious foods, education and adequate housing, need to gather more information before investing in financial institutions in Ghana and losing of funds invested as a results of the collapse of some financial institutions in Ghana due to the withdrawal of their licences. From the findings of this study it is suggested that a future studies should be carried out by using additional independent variables as the independent variables used in this study explain on 32.3 per cent of financial threat in Ghana using the Nagelkerke $R^{2}$.

\section{References}

Afolabi, J.J. (2018), "Feature: why the local banks in Ghana are collapsing", available at: www. ghanaweb.com/GhanaHomePage/business/Feature-Why-the-local-banks-in-Ghana-areCollapsing-669688 (accessed 8 July 2019).

Anokye, K. (2019), "Financial sector cleanup: the good, bad and ugly", available at: www.ghanaweb. com/GhanaHomePage/features/Financial-sector-cleanup-The-good-bad-and-ugly-778943 (accessed 4 July 2019).

Bank of Ghana (2019a), "Frequently asked questions (FAQs). Revocation of the licences of insolvent savings and loan companies, finance house companies, and non-bank financial institutions", available at: www.bog.gov.gh/notice/faqs-revocation-of-licences-of-insolvent-savings-and-loanscompanies-finance-house-companies-and-non-bank-financial-institutions/ (accessed 8 July 2019).

Bank of Ghana (2019b), "Press release: notice of revocation of licences of insolvent microcredit companies", available at: www.bog.gov.gh/wp-content/uploads/2019/07/NOTICE-OF-REVOCATIONOF-LICENCES-OF-INSOLVENT-MICROCREDIT-COMPANIES.pdf (accessed 8 July 2019).

Chen, J. (2019), "Ponzi scheme. Investopedia.com", available at: www.investopedia.com/terms/p/ ponzischeme.asp (accessed 8 July 2019).

Eben (2016), "DKM finance diverted GHф77m into subsidiaries", available at: www.thefinderonline. com/life-style/item/6336-dkm-micro-finance-diverted-gh-77m-into-subsidiaries (accessed 8 July 2019).

Frimpong, E.D. (2018), "BOG collapses 5 banks into consolidated bank Ghana Ltd", available at: www. graphic.com.gh/business/business-news/bog-collapses-5-banks-into-consolidated-bank-ghana-ltd. html (accessed 11 July 2019).

GBN (2016), "DKM diamond microfinance, Jaster motors to be liquidated", available at: www. ghanabusinessnews.com/2016/01/18/dkm-diamond-microfinance-jastar-motors-to-be-liquidated/ (accessed 3 July 2019).

Joy Business (2017), "GCB takeover as BOG withdraws licenses of UT, capital bank", available at: www.myjoyonline.com/business/2017/August-14th/bog-withdraws-license-of-ut-capital-bankappoints-gcb-to-take-over-institutions.php (accessed 8 July 2019).

Kabiru, T. and Abdullahi, U.U. (2016), "Binary logistic regression analysis on admitting students using jamb score", Journal of Current Research, Vol. 8 No. 1, pp. 25235-25239.

Kaplan, M.S., Huguet, N., Caetano, R., Giesbrecht, N., Kerr, W. and McFarland, B.H. (2015), “Economic contraction, alcohol intoxication and suicide: analysis of the national violent death reporting system”, Injury Prevention, Vol. 21 No. 1, pp. 35-41.

Larbi, S.O. (2016), "Collapse of DKM due to unsustainable services - finance minister", available at: https://kasapafmonline.com/2016/02/collapse-of-dkm-due-to-unsustainable-services-financeminister/ (accessed 10 July 2019).

Lisa, F., Zdravko, M. and Esther, G. (2017), "Financial threat and individuals' willingness to change financial behavior", Review of Behavioural Finance, Vol. 9 No. 2, pp. 128-147. 
Myjoyonline.com (2018), "Full BOG statement: five banks dissolved”, available at: www.myjoyonline. com/business/2018/august-1st/full-bog-statment-five-banks-dissolved.php (accessed 18 July 2019).

Ofori-Atta, K. (2018), "The budget statement and economic policy 2019 financial year of the government of Ghana", available at: www.mofep.gov.gh/sites/default/files/budget-statements/ 2019-Budget-Statement-and-Economic-Policy_.pdf (accessed 8 July 2019).

Oka (2018), "SEC orders Menzgold to shut down trading immediately", available at: www.myjoyonline. com/news/2018/September-12th/sec-orders-menzgold-to-shut-down-trading-immediately. php (accessed 12 July 2019).

Owusu, B.K. (2018), "Ghana banking system failure: the need for restoration of public trust and confidence", International Journal of Business and Research, Vol. 8 No. 10, pp. 1-5.

Sarfo, A. (2018), "Poor corporate governance and the collapse of banks", available at: https:// thebftonline.com/2018/features/poor-corporate-governance-and-the-collapse-of-banks/ (accessed 18 July 2019).

Securities and Exchange Commission Ghana (2018), "Public notice: clarification of previous directives to Menzgold and fund managers", available at: https://sec.gov.gh/wp-content/uploads/PublicNotices/PUBLIC_NOTICE_CLARIFICATION_OF_PREVIOUS_DIRECTIVES_TO_MENZGOLD_ AND_FUND_MANAGERS.pdf (accessed 15 July 2019).

Securities and Exchange Commission Ghana (2019), "Notice of revocation of licences of fund management companies and notification to the registrar of companies", available at: https://sec. gov.gh/wp-content/uploads/Public-Notices/PUBLIC_NOTICE_OF_REVOCATION_OF_LICENCES_ OF_FUND_MANAGEMENT_COMPANIES_AND_NOTIFICATION_TO_THE_REGISTRAR_ OF_COMPANIES.pdf (accessed 8July 2019).

The Financial Intelligence Centre (2016), "Bank of Ghana (BOG) revokes licenses of 70 money lending and microfinance companies", available at: https://fic.gov.gh/bank-of-ghana-bog-revokeslicenses-of-70-money-lending-and-microfinance-companies/ (accessed 8 July 2019).

Vaultz (2019), "Ghana's rising Ponzi schemes - a case of institutional failures?”, available at: https:// thevaultzmag.com/index.php/vaultz-news/local-news/the-focus/ghana-s-rising-ponzi-schemes-acase-of-institutional-failures (accessed 8 July 2019).

\section{Corresponding author}

Edmond Ofori can be contacted at: ofmond@yahoo.com

For instructions on how to order reprints of this article, please visit our website: 